\title{
A Summary of the Research Thinking of Administrative Secretary Work in Higher Vocational College
}

\author{
Yongming $\mathrm{Xu}^{1, \mathrm{a}}$
}

\author{
${ }^{1}$ Dalian Vocational and Technical College (Dalian Open University), Dalian City, Liaoning Province, 116035 \\ ${ }^{a} x y m @ d l v t c . e d u . c n$
}

\begin{abstract}
The administrative secretary is an important post set up in higher vocational colleges. It plays an important role in communicating the relationship between superiors and subordinates, and assumes important responsibilities.Generally speaking, the work of the administrative secretary is more cumbersome and complicated, the work content is more, and it is a comprehensive work.Under the current social situation, the development of higher vocational colleges has put forward higher requirements for the work of administrative secretaries, requiring administrative secretaries to continuously improve themselves, develop themselves, and further optimize their service and management levels. This article analyzes the main points and responsibilities of administrative secretaries in higher vocational colleges, and discusses the countermeasures and methods for effective management of administrative secretaries, improving work efficiency, and optimizing service quality, hoping to improve the quality level of administrative secretary management and work in higher vocational colleges, and promote the sustainable and healthy development of higher vocational colleges ${ }^{[1]}$.
\end{abstract}

Keywords: Higher Vocational Colleges, Administrative Secretary, Main Points of Work

\section{INTRODUCTION}

The administrative secretaries of higher vocational colleges belong to the grass-roots administrative managers, and they bear important responsibilities and play an important role in the school's grass-roots management affairs.Its work is more complicated,Its work is relatively complicated, such as communicating with superiors and subordinates, completing tasks assigned by the leaders, and providing effective services for the implementation of teaching and auxiliary work. With the continuous deepening of education and teaching reform in higher vocational colleges and the continuous development of higher vocational colleges, higher requirements are also put forward for administrative secretarial work. The administrative secretary needs to accurately grasp the content, main points and main responsibilities of his work, and continuously improve and optimize his management level, service level, work efficiency and service quality in daily work practice, so as to promote the sustainable development of the school Contribute greater value and strength .Therefore, it is necessary to explore and analyze the characteristics and main points of administrative secretarial management work, and to improve the countermeasures and methods of administrative secretarial management service level.

\section{THE MAIN CONTENT AND RESPONSIBILITIES OF ADMINISTRATIVE SECRETARIES IN HIGHER VOCATIONAL COLLEGES}

The administrative secretary of a higher vocational college is the manager of the school's daily work. The development and implementation of administrative secretarial work is mainly based on ensuring operations. The content of its work is relatively complicated and diversified, such as basic document writing, file management, assistance management, daily administrative affairs, skilled operation and use of office automation equipment, etc.There are also many service targets, including guides, teachers, students, docking with relevant departments such as the Academic Affairs Office, the Personnel Office, and the General Affairs Office to assist in the communication and coordination 
management between them.As a staff assistant of the leader, it needs to complete various tasks assigned by the superior leader, and he also needs to assist the leader to coordinate various tasks in the school and department, and serve the development and implementation of teaching, teaching assistance and student management.They are required to have strong writing and application skills, listening and speaking skills, high work efficiency, execution skills, and adaptability, they also need to strengthen their sense of teamwork and clear work regulations.

The content and responsibilities of administrative secretarial work in higher vocational colleges are mainly manifested in the following aspects. The personnel engaged in administrative secretarial work are required to have an accurate and comprehensive grasp of this, to ensure the efficient and standardized development and implementation of their work.

1) Do a good job in daily administrative affairs. Such as supervising and managing the safety and environmental sanitation in the department;responsible for the daily department of documents and notices receipt and dispatch and supervision; do the daily reception work well; complete other affairs and tasks assigned and assigned by the leaders of the department;responsible for the drafting and verification of materials such as general administrative documents and administrative leaders' speeches within the department;Drafting of records and minutes of administrative work meetings;supervise and inspect the implementation of administrative work plans, decisions, etc., and do a good job of feedback;Custody of seals, etc [2].

2) Do a good conference management. When the meeting is held and the related activities of the department are held, it need to do a good job in the organization; in accordance with the requirements of the meeting, supervise the layout of the venue; do a good job of reception in related meetings and activities; at the meeting, it also need to do a good job in writing, publicizing, and recording the outline of the meeting; after the meeting, it need to promptly communicate the teaching plans, teaching instructions, and content of the meeting put forward in the meeting to ensure that they can be effectively implemented and implemented in the department ${ }^{[3]}$.

3) Responsible for the organization and management of related documents. Such as the various conferences in the department; the student's school status and study; superior documents and approval documents; the sorting, classifying, filing and recording of materials and archives; the collection, sorting, summarization, transmission and reporting of the daily situation of colleges and departments and related data; and do a series of documents and archives confidential work, including internal information of the department, personnel information, meeting content, etc.Strictly handle and resolve students' suspension, withdrawal, resumption, transfer and other situations and problems in accordance with the school's various rules and regulations, and do a good job of feedback and reporting on students' specific situations ${ }^{[4]}$.

4) Assist in teaching. The administrative secretary also needs to take on his own responsibilities in assisting teaching.For example, the management of student performance, the arrangement of students' mid-term, final, make-up exam, retake, and other important certificate exams (levels 4 and 6) and other related matters in strict accordance with relevant regulations, and make relevant reports and reports jobs; supervise the development and implementation of teaching work, assist leaders in the investigation, evaluation and analysis of teachers, teaching quality, etc. in the department, inspection and analysis of teaching progress and staged teaching conditions to ensure high quality of teaching .

5) Do a good job in the management of materials. Assist teachers in the development and implementation of teaching work, and do a good job in purchasing related teaching materials and office supplies; assist in the procurement, maintenance and maintenance of office equipment in colleges and departments ${ }^{[5]}$.

6) Assist in the resolution and handling of emergencies within the department. When problems and emergencies such as teachers and students are difficult to solve and deal with within the department, the administrative secretary needs to assume his own responsibilities, urgently contact relevant person in charge, and assist in the resolution of the incident, so as to avoid further incidents. Expansion causes greater impact and losses.

7) Assist department leaders to manage administrative affairs. The administrative secretary is the staff assistant of the leader. In his work, he needs to assist the leaders in the department to do the administrative work. In accordance with the relevant regulations, he must complete the tasks assigned by the superiors.

8) Do a good job of distributing the upper information and uploading the lower information. There are many targets of administrative secretarial services, including guides, teachers, students, and related departments such as the Academic Affairs Office, the Personnel Office, and the General Affairs Office. The development and implementation of its work is a bridge connecting these subjects and communicating with these departments. It is necessary in actual work. Do a good job in distributing the upper information and uploading the lower information.That is, to convey some documents, approvals, teaching plans, index requirements, etc. of the superiors to specific 
departments and personnel, and supervise their implementation and implementation; Provide timely feedback on work status and development status, existing problems, needs and demands ${ }^{[6]}$.

\section{CHARACTERISTICS OF ADMINISTRATIVE SECRETARIAL WORK IN HIGHER VOCATIONAL COLLEGES}

The development and implementation of administrative secretarial work in higher vocational colleges ensures the effective implementation and implementation of various decisions within the colleges and departments, communicates and informs various instructions, documents and plans, and promotes the smooth development and implementation of teaching, research and teaching in the colleges and departments. And other aspects play an important role. The administrative secretarial work of higher vocational colleges has its own characteristics. Only by accurately grasping these characteristics and requirements can we adopt targeted strategies and methods when cultivating and improving administrative secretaries, and effectively improve the level and work of administrative secretarial management services. Efficiency and promote the sustainable and healthy development of higher vocational colleges.

1) Serviceability. The administrative secretary is responsible for the management and service work in the department, and is the service provider who uploads and distributes, and service is the core performance of his work. There are many targets of administrative secretarial services, including leaders, teachers, students, etc., and it is necessary to undertake the work of bridging the middle, do a good job in communication between leaders and teachers, and pass on the rules and regulations of relevant departments, administrative documents, and superiors to faculty and staff. Work requirements; and accept teachers' feedback, opinions, and suggestions, convey the problems and demands encountered by teachers in their work to their superiors, and report their feedback to leaders and related departments; provide services to students, accurately grasp and analyze students' Age, mentality, needs, strengthen communication with students, and patiently help students solve and deal with problems and problems in study, life and practice.

2) Coordination. The administrative secretary plays an important role in coordinating the communication and cooperation between relevant personnel and relevant departments, such as assisting leaders to implement various tasks, documents and policies; assisting leaders in handling and resolving various conflicts and disputes; strengthening the relationship with the hospital, personnel, and Communication and collaboration between relevant departments such as educational affairs; handle the relationship between teachers, teaching, students, and schools, and ensure the standardized development and implementation of various daily affairs in the colleges and departments, and improve the efficiency of the work in the colleges and departments. When the administrative secretary is at work, he needs to actively collect and transmit various instructions and plans from superiors and subordinates, coordinate with the leaders of various departments in the department, make arrangements for daily affairs, teaching and management plans, and make arrangements for them. It is accurately passed to all relevant departments and personnel, and it is necessary to answer questions and urge improvements in the process of supervision and implementation.

3) Principle. Mainly refers to the daily work of the administrative secretary that needs to be carried out in strict accordance with the school's rules and regulations. When dealing with and solving various problems, it must be pragmatic, objective and calm, fair and open, and be able to handle it flexibly, To make leaders, teachers, and students more trustworthy and improve their satisfaction.

4) Supportability. The development and implementation of administrative secretarial work cannot be separated from the leadership and exist independently. All of its work needs to be closely focused on the work and content of the leadership and the relevant subordinate departments to better assist the implementation of the department management and teaching practice. The administrative secretary needs to supervise and follow up the tasks and tasks assigned by the leaders to ensure their effective implementation.

5) Regularity. The daily work of the administrative secretary has a certain regularity, such as assisting the superior in teaching management, daily work statistics, file sorting, classification and summarization, etc., although the work is relatively complicated, large in number, and trivial, and administration is also required. The secretary's scientific arrangements must not be delayed, but the efficiency of the work must be ensured.

\section{THE CURRENT SITUATION OF ADMINISTRATIVE SECRETARIAL WORK IN HIGHER VOCATIONAL COLLEGES}

\subsection{School}

1) Some higher vocational colleges do not pay enough attention to the construction of administrative secretaries and lack in-depth understanding of administrative secretarial work. Many teachers and departments have a discriminatory psychology towards administrative secretaries, thinking that they only need to do a good job of answering phone calls, sending and 
receiving documents, etc. That's it, the arrangement for the administrative secretary's work lacks rationality. 2) The investment in the construction of the administrative secretarial team is relatively small, and this part of the professional staff is relatively small, resulting in a very complicated and complicated work. 3) There is a lack of regular training for administrative secretaries, and there are fewer opportunities to go out to participate in training and learning. 4) The salary level of administrative secretaries is not high, the opportunities for promotion are relatively few, etc., and the lack of a systematic and complete evaluation and assessment system has seriously affected the efficiency of administrative secretaries and the quality of services.

\subsection{Personal aspects}

1) The ability of administrative secretaries needs to be improved.The work of administrative secretaries in higher vocational colleges involves a wide range, such as the registration of various documents, uploading and issuing, meeting notices and records, visits and receptions, handling of basic management affairs of colleges and departments, student management and temporary assignments assigned by leaders Work, etc., and even have to deal with many tasks that are not included in the scope of their job responsibilities. Many administrative secretaries are not fully qualified for these tasks, and are prone to dissatisfaction in these complicated tasks, which affects the quality and efficiency of service and management.2) Inaccurate thinking and perception. Many people just use the administrative secretarial stage as a springboard, and their goal is to shift to the teaching establishment. They lack enough enthusiasm when they work, work too passively, and even refer to where to play. 3) In tedious work, boredom is prone to appear, there is also the phenomenon of procrastinating work, and the work efficiency is not high.

\section{COUNTERMEASURES AND METHODS TO IMPROVE THE EFFICIENCY OF ADMINISTRATIVE SECRETARIAL WORK AND MANAGEMENT IN HIGHER VOCATIONAL COLLEGES}

\subsection{Correct the working attitude of the administrative secretary}

The administrative secretaries of higher vocational colleges need to have an accurate understanding and cognition of their own work content, job responsibilities, work characteristics, etc., and ensure that they can maintain a positive attitude in the daily work process, correct their work and service attitudes, and be clear Position your own work, and make full use of your subjective initiative in the process of work, and devote yourself to your work actively and enthusiastically.In the face of complicated work, problems and news in many aspects such as leadership, teachers, students, teaching, management, etc., they can also solve and deal with them in a timely, rapid, standardized and efficient manner.Be kind and patient when facing visitors, teachers and students' feedback, and provide efficient services.In the process of daily work development and implementation, we can do things strictly in accordance with the school's rules and regulations. When dealing with and solving various problems, we can be pragmatic, objective and calm, fair and open, and can't engage in favoritism. When faced with complex and repetitive things, do not be irritable, not bored, not complaining, not complaining, not getting angry, and ensure that you are comfortable in the work process. When encountering difficulties, assist as soon as possible to find a way to solve and deal with the problem.In addition, administrative secretaries need to strengthen their sense of service, take the initiative to assume responsibilities in the development and implementation of teaching and research work, serving students and the development and implementation of school management activities, and effectively improve the work efficiency and management level of administrative secretaries. And service quality.

\subsection{Improve the overall quality of administrative secretaries}

Administrative secretaries need to consciously improve their own comprehensive quality and ability level, strengthen their own quality construction, improve their professional level and work ability, in order to be better qualified for the job.The first is that higher vocational colleges need to provide targeted training and education for administrative secretaries, and provide them with learning and exercise opportunities, so as to encourage administrative secretaries to continuously improve their overall quality and their own ability level, so that they can face For complex tasks, we can also consider and analyze as a whole, plan and arrange scientifically and rationally, and ensure that the work is completed on time, with quality, quantity, and time.For example, it is necessary to strengthen ideological education to ensure that they can correct their attitudes and have a strong sense of service in the process of work.Strengthen the training and education of professional management knowledge and skills, continuously enrich their work experience, ensure that they master advanced management methods and improve their management level.The second is to strengthen the awareness of learning, to guide the administrative secretaries to learn professional knowledge related to their own work, and the administrative secretaries themselves should also use their spare time to learn, such as secretarial knowledge, basic-level post management knowledge, management 
knowledge in teaching and scientific research, and use of information technology Improve your work ability, document processing ability, writing ability, information research ability, innovative thinking ability, work efficiency and quality level.

\subsection{Strengthen the training of administrative secretaries}

Higher vocational colleges need to fully realize the importance of administrative secretarial work, and further increase the degree of attention and investment in the construction of the administrative secretarial team. One is to organize and carry out regular exchanges and seminars for administrative secretaries to guide them to learn from others' advanced experience and methods; higher vocational colleges should provide opportunities and platforms for administrative secretaries' personal study and training, outings for visits, and outings for study and seminars. , Provide professional and systematic training and re-education opportunities for administrative secretaries, and guide administrative secretaries to continuously improve and optimize themselves, so as to improve their work efficiency and work level. Second, according to the specific work situation, job responsibilities and content of the administrative secretary, appropriately improve its salary and welfare level, further improve the indicators and standards of salary evaluation, and improve and perfect the administrative secretary's salary system and incentive mechanism, so as to guide the administration The secretary worked harder ${ }^{[7]}$.

\subsection{Establish a correct concept and awareness}

Higher vocational administrative secretaries need to strengthen their awareness of three aspects. One is to strengthen the awareness of learning, to constantly improve and improve oneself at work, to enrich oneself through training and learning, to broaden the scope of knowledge, and to improve the level of ability in listening, speaking, reading, writing, and use.Second, to strengthen the awareness of rules does not mean that administrative secretaries are required to stick to the rules, orderly, and immutable, but to comply with job responsibilities, work requirements, professional ethics, and discipline requirements.Third, strengthening the sense of service does not require administrative secretaries to take over all the affairs in their work, but to do a good job of assistance, service, and communication within the scope of their duties.

\section{CONCLUSION}

To sum up, the administrative secretaries of higher vocational colleges play an important role in the management and service of the work development and implementation of the departments of higher vocational colleges, in order to effectively improve the efficiency of their work, the level of management and the quality of services., To promote the sustainable development of higher vocational colleges. It is required to accurately grasp the work characteristics, work content, and work responsibilities of administrative secretaries in higher vocational colleges. Judging from the current status of administrative secretarial work in higher vocational colleges, there are still many shortcomings and problems in its work, and further improvement and optimization are needed to effectively improve the quality of administrative secretarial services and the level of management. Provide targeted training and education for administrative secretaries of higher vocational colleges to promote them to strengthen their sense of service, correct work attitudes, maintain a good attitude, improve their own abilities and comprehensive qualities, to ensure that they can still be fast in the complex work process Solve problems, handle various relationships and work well, and contribute their strength and value to the promotion of the development of the school and the efficient development and implementation of teaching work.

\section{REFERENCES}

[1] Xianglan Zhang. Research on the work of administrative secretaries[J]. Journal of Capital Normal University, 2017(12).

[2] Yanting Lin. Refined management in administrative secretary office work of colleges and universities[J]. Office Business, 2016(14): 86.

[3] Sumei Tang. Talk about some understandings of the administrative secretarial work of colleges and universities[J]. Education Modernization, 2018, 5(50): 138-139.

[4] Xuemei Chen. The exploration and practice of two-level teaching management in higher vocational colleges-based on the perspective of teaching secretary[J]. Educational Modernization, 2016(27): 274-275+278.

[5] Xiaoyun Hao. Cultivation of the work consciousness of administrative secretaries in the departments of private higher vocational colleges[J]. Science and Technology Wind, 2015(14):248-249.

[6] Heda Bai. An analysis of the work characteristics of administrative secretaries in the lower-level departments of independent colleges [J]. Oriental Corporate Culture, 2014 (03): 365.

[7] Yanping Yang. Exploration of the characteristics and laws of administrative work in private colleges and universities[J]. Journal of Jiamusi Education College, 2013(03): $104+114$. 